\title{
ETHNOGEOGRAPHICAL COINCIDENCE OF ENDEMIC KAPOSI'S SARCOMA AND AFRICAN BURKITT'S LYMPHOMA IN WESTERN KENYA
}

\author{
KAN TORIYAMA \\ Received September 25 1987/Accepted March 11988
}

\begin{abstract}
Geopathological studies on endemic Kaposi's sarcoma (KS) and African Burkitt's lymphoma (BL) in western Kenya were performed, and revealed that $\mathrm{KS}$ and $\mathrm{BL}$ had relatively same geographical and ethnical distribution. The western region of Kenya stands almost exactly astride the equator. It accounts for almost one third of the whole country in area and about one half in population. Western Kenya is composed of three provinces; Nyanza Province, Western Province and Rift Valley Province. Out of 25,343 surgical pathological specimens at provincial hospitals in Nyanza, Western and Rift Valley for 8 years during 1979 to 1986, 124 and 135 cases were histologically diagnosed as $\mathrm{KS}$ and BL respectively. Frequency in all malignant tumors was $2.92 \%$ (KS) and $3.18 \%$ (BL). The high incidence of KS was found between the age of 50 and 59 , while all BL cases were found under 22 years. The male to female ratio was 8.4:1.0 in KS and 1.2:1.0 in BL. The incidence of $\mathrm{KS}$ and $\mathrm{BL}$ per 100,000 population in each province is as follows: a) $2.12(\mathrm{KS})$ and $3.54(\mathrm{BL})$ in Nyanza Province, b) $1.80(\mathrm{KS})$ and $1.20(\mathrm{BL})$ in Western Province, and c) 1.11 (KS) and $0.68(\mathrm{BL})$ in Rift Valley Province. Nyanza Province and Western Province are tropical savannah areas, whereas Rift Valley Province is a tropical highland. The incidence of KS and BL per 100,000 population among main ethnic groups in western Kenya is as follows: the Luo, the main inhabitants of Nyanza Province around Lake Victoria, showed the highest incidence of KS (2.56) and BL (4.35), followed by the Luhya, the main inhabitants of Western Province, the Kalenjin, the inhabitants of the tropical highland in Rift Valley Province, and the Kisii, the inhabitants of highland area of Nyanza Province. The Luo are descended from the Nilotic groups and the Luhya belong to the Bantu. No case of KS and only a few cases of BL were found among the inhabitants of desert or semi-desert areas. No other tumors showed above mentioned characteristics. The geographical and ethnical coincidence of KS and BL was more clear in the child population than in the adult. These results suggest that there is a geographical coincidence of KS and BL based on same etiological cofactors including high temperature, high humidity, unknown transmissible agents, and probably genetic factors and life styles. This was mainly demonstrated in Nyanza Province around Lake Victoria in western Kenya.
\end{abstract}

\section{INTORODUCTION}

Kaposi's sarcoma (KS; initially called Idiopathisches Multiples Pigment Sarkom der

Department of Pathology, Institute of Tropical Medicine, Nagasaki University

12-4 Sakamoto-machi, Nagasaki 852, Japan

Research Clearance Permit, Republic of Kenya No. OP. 13/001/8 c 224/12, 36.

Supported by Grants under the Monbusho (The Ministry of Education, Science and Culture, Japan) International Scientific Research Program No. 504153, 56043047, 58041054, 59043049, 61041063, and 62043059 . 
Haut) was first described in eastern Europe (Kaposi, 1872). Up to the present day, many cases of KS have been reported from European and North American countries and a relatively high incidence of KS has appeared among the inhabitants of eastern Europe and Mediterranean countries, as well as those of Jewish origin in central Europe (Bluefarb, 1957; Oettle, 1962; Rothman, 1962). The first report of African KS from French Cameroon was made by Jojot and Laigret in 1922. Nowadays, it is well known that endemic KS is more prevalent in African continent than any other part of the world (Oettle, 1962; Maclean, 1963). When the ratio of endemic KS to all malignant tumors was considered, the highest value was found in central Africa with the incidence of endemic KS decreasing with distance away from this area (Cox and Helwig, 1959; Cook, 1962; Davies and Lothe, 1962; Keen, 1962; Oettle, 1962; Maclean, 1963; Slavin et al., 1969; Taylor et al., 1971a; Schmid, 1973; Toriyama et al., 1987a). It has been reported that cytomegalovirus (CMV) is etiologically concerned with KS in Africa (Burkes et al., 1985). Since the occurrence of the first Aquired Immunodeficiency Syndrome (AIDS) case (Centers for Disease Control, 1981a), KS has been considered one of the main complications of AIDS (Centers for Disease Control, 1981b; Friedman-Kien et al., 1981). Several cases of African endemic KS contained viral inclusions, and European and American patients with KS were found to possess increased serum-levels of antibody to CMV when compared with normal controls and patients with other malignancies (Giraldo et al., 1972a, 1972b, 1975; Boldogh et al., 1981). However, KS in AIDS (epidemic type) is a little different from endemic KS in Africa in its manifestations (Toriyama et al., 1987b). In North America, the incidence of malignant B-cell lymphoma which is also related to AIDS has been increasing (Ziegler et al., 1982, 1984; Levine et al., 1984, 1985).

Burkitt's lymphoma (BL), a malignant B-cell lymphoma, is also endemic throughout most of tropical Africa (Burkitt, 1962). Epstein-Barr virus (EBV) is now known to be the causative agent of BL (Epstein et al., 1964; Old et al., 1966; de Schryver et al., 1969; Henle et al., 1969, 1973; Gunven et al., 1970; zur Hausen et al., 1970; Kaschka-Dierich et al., 1976). It has been suggested that EBV may initiate a lymphoid tumor of a susceptible individual whose immunological response has been altered by malaria, especially Plasmodium falciparum (Hutt, 1970).

Across African continent between the latitudes of approximately $15^{\circ}$ north and south of the Equator, BL appears to be highly prevalent (lymphoma belt) (Burkitt, 1962, 1966, 1969). Although it is supposed that the lymphoma belt and the areas with the high incidence of KS are overlapping (Burkitt, 1970), no reports clarifying the geographical and ethnical coincidence of endemic KS and African BL have been published up to the present day. It is the aim of this study to discuss in more detail the geographical and ethnical distribution as well as some etiological cofactors between endemic KS and African BL in western Kenya.

\section{MATERIALS AND METHODS}

This study was based on the histopathological examinations of surgical specimens, almost all of which were performed in the Histology Departments of two hospitals, the Rift Valley Provincial General Hospital in Nakuru and the Nyanza Provincial General Hospital in Kisumu, Kenya. During the eight-year period between 1979 and 1986, a total of 25,343 surgical specimens from Nyanza, Western, and Rift Valley Provinces in western Kenya were examined histologically for $\mathrm{KS}$ and $\mathrm{BL}$. Relevant information and clinical data were 
collected as accurately as possible, with attention being paid to age, sex, ethnic group, place of residence, and macroscopic appearances. The diagnoses of KS and BL were based on clinical and histological grounds. Histological examinations were performed using H. E., periodic acid Schiff (P.A.S.), reticulum, elastic van Gieson and Azan Mallory stains. A demographic structure was obtained from the Kenya Population Census 1979 (Government of Kenya, 1979)

Table 1 Incidence of Kaposi's sarcoma (KS) and Burkitt's lymphoma (BL) amongst malignant tumors (1979-1986)

\begin{tabular}{|c|c|c|c|c|c|c|c|}
\hline Year & $\begin{array}{c}\text { No. of } \\
\text { surg. specimen }\end{array}$ & $\begin{array}{l}\text { No. of } \\
\text { malig. tum }\end{array}$ & & $\begin{array}{l}\text { No. of } \\
\text { KS }\end{array}$ & $\frac{\mathrm{KS}}{\text { malig. tumor }}(\%)$ & $\begin{array}{l}\text { No. of } \\
\text { BL }\end{array}$ & $\frac{\mathrm{BL}}{\text { malig. tumor }}(\%)$ \\
\hline \multirow[t]{4}{*}{1979} & 1,179 & Male & 102 & 2 & 1.96 & 4 & 3.92 \\
\hline & & Female & 76 & 0 & - & 1 & 1.32 \\
\hline & & Unknown & 7 & 0 & - & 0 & - \\
\hline & & (Total) & 185 & 2 & 1.08 & 5 & 2.70 \\
\hline \multirow[t]{4}{*}{1980} & 3,359 & Male & 262 & 12 & 4.58 & 4 & 1.53 \\
\hline & & Female & 318 & 1 & 0.31 & 0 & - \\
\hline & & Unknown & 3 & 0 & - & 0 & - \\
\hline & & (Total) & 583 & 13 & 2.23 & 4 & 0.69 \\
\hline \multirow[t]{4}{*}{1981} & 3,652 & Male & 336 & 22 & 6.55 & 9 & 2.68 \\
\hline & & Female & 368 & 5 & 1.36 & 9 & 2.54 \\
\hline & & Unknown & 5 & 1 & 20.00 & 0 & - \\
\hline & & (Total) & 709 & 28 & 3.95 & 18 & 2.54 \\
\hline \multirow[t]{4}{*}{1982} & 4,401 & Male & 213 & 24 & 11.27 & 6 & 1.98 \\
\hline & & Female & 315 & 2 & 1.36 & 7 & 2.22 \\
\hline & & Unknown & 25 & 1 & 4.00 & 0 & - \\
\hline & & (Total) & 553 & 27 & 4.88 & 13 & 2.35 \\
\hline \multirow[t]{4}{*}{1983} & 3,905 & Male & 303 & 8 & 2.64 & 6 & 1.98 \\
\hline & & Female & 253 & 0 & - & 15 & 5.93 \\
\hline & & Unknown & 19 & 0 & - & 0 & - \\
\hline & & (Total) & 575 & 8 & 1.39 & 21 & 3.65 \\
\hline \multirow[t]{4}{*}{1984} & 2,493 & Male & 198 & 8 & 4.04 & 15 & 7.58 \\
\hline & & Female & 216 & 0 & - & 3 & 1.39 \\
\hline & & Unknown & 1 & 0 & - & 1 & 100.00 \\
\hline & & (Total) & 415 & 8 & 1.93 & 19 & 4.58 \\
\hline \multirow[t]{4}{*}{1985} & 3,914 & Male & 323 & 18 & 5.57 & 17 & 5.26 \\
\hline & & Female & 424 & 3 & 0.70 & 16 & 3.77 \\
\hline & & Unknown & 9 & 0 & - & 0 & - \\
\hline & & (Total) & 756 & 21 & 2.65 & 33 & 4.37 \\
\hline \multirow[t]{4}{*}{1986} & 2,440 & Male & 180 & 15 & 8.33 & 12 & 6.67 \\
\hline & & Female & 271 & 2 & 0.74 & 10 & 3.69 \\
\hline & & Unknown & 16 & 0 & - & 0 & - \\
\hline & & (Total) & 467 & 17 & 3.64 & 22 & 4.71 \\
\hline \multirow[t]{4}{*}{ Total } & 25,343 & Male 1 , & 917 & 109 & 5.69 & 73 & 3.80 \\
\hline & & Female 2, & 241 & 13 & 0.58 & 61 & 2.72 \\
\hline & & Unknown & 85 & 2 & 2.35 & 1 & 1.18 \\
\hline & & (Total) 4 & 243 & 124 & 2.92 & 135 & 3.18 \\
\hline
\end{tabular}


Table 2 Age and sex distribution of 124 cases of Kaposi's sarcoma (KS)

\begin{tabular}{crccr}
\hline \multirow{2}{*}{ Age Group } & \multicolumn{4}{c}{ Sex } \\
\cline { 2 - 5 } & Male & Female Unknown & Total \\
\hline $0-4$ & 6 & 0 & 0 & 6 \\
$5-9$ & 4 & 2 & 0 & 6 \\
$10-14$ & 3 & 1 & 0 & 4 \\
$15-19$ & 1 & 1 & 0 & 2 \\
$20-24$ & 4 & 0 & 0 & 4 \\
$25-29$ & 7 & 1 & 0 & 8 \\
$30-34$ & 4 & 0 & 0 & 4 \\
$35-39$ & 5 & 0 & 0 & 5 \\
$40-44$ & 9 & 1 & 0 & 10 \\
$45-49$ & 7 & 2 & 0 & 9 \\
$50-54$ & 15 & 1 & 0 & 16 \\
$55-59$ & 7 & 0 & 0 & 7 \\
60 and over & 17 & 0 & 0 & 17 \\
"Child"* & 1 & 0 & 0 & 1 \\
"Adult"** & 14 & 3 & 0 & 17 \\
Unknown & 5 & 1 & 2 & 8 \\
\hline Total & 109 & 13 & 2 & 124 \\
\hline
\end{tabular}

Table 3 Age and sex distribution of 135 cases of Burkitt's lymphoma (BL)

\begin{tabular}{cccc}
\hline \multirow{2}{*}{ Age Group } & \multicolumn{3}{c}{ Sex } \\
\cline { 2 - 4 } & Male & Female Unknown & Total \\
\hline
\end{tabular}

$\begin{array}{lllll}0-4 & 18 & 2 & 0 & 20\end{array}$

$5-9 \quad 30 \quad 29 \quad 1 \quad 60$

$\begin{array}{lllll}10-14 & 14 & 17 & 0 & 31\end{array}$

$\begin{array}{lllll}15-19 & 1 & 6 & 0 & 7\end{array}$

20 and over $\quad 0 \quad 1 \quad 0 \quad 1$

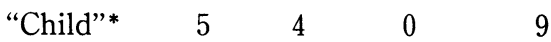

\begin{tabular}{crrrr} 
Unknown & 5 & 2 & 0 & 7 \\
\hline Total & 73 & 61 & 1 & 135
\end{tabular}

* Exact age is unknown, probably under 14 years of age.

* * Exact age is unknown, probably over 15 years of age.

\section{RESULTS}

\section{Incidence of KS and BL amongst malignant tumors}

During the eight-year period between 1979 and 1986, out of 25,343 surgical specimens, 4,243 specimens were malignant tumors. Among them 124 cases were histologically diagnosed as KS and 135 cases as BL. Table 1 shows the ratio of KS and BL to all malignant tumors during the period; $1.08 \%$ and $2.70 \%$ in $1979,2.23 \%$ and $0.69 \%$ in $1980,3.95 \%$ and $2.54 \%$ in $1981,4.88 \%$ and $2.35 \%$ in $1982,1.39 \%$ and $3.65 \%$ in $1983,1.93 \%$ and $4.58 \%$ in $1984,2.65 \%$ and $4.37 \%$ in 1985 , and $3.64 \%$ and $4.71 \%$ in 1986 respectively. The total incidence of KS and $\mathrm{BL}$ amongst all malignant tumors in western Kenya for the eight-year period was $2.92 \%$ and $3.18 \%$ respectively.

Age and sex distribution of $K S$ and $B L$

Tables 2 and 3 indicate the age and sex distribution of KS and BL respectively. The high incidence of KS cases was found between the age of 50 and 59 , while all BL cases were found under 22 years. The male to female ratio was 8.4:1.0 in KS and 1.2:1.0 in BL. The highest incidence of BL cases was found in the 5-9-year-old age group. The analyses of sex distribution revealed that males had significantly higher rates in $\mathrm{KS}(\mathrm{p}<0.001)$ and $\mathrm{BL}(\mathrm{p}<$ 0.05 ) than females (by the Chi-square test, using 4,243 cases of malignant tumors). 
Table 4 Anatomical distribution of 124 cases of Kaposi's sarcoma (KS)

\begin{tabular}{|c|c|c|c|c|c|c|c|c|c|c|c|c|c|}
\hline \multirow{3}{*}{ Localization } & \multicolumn{13}{|c|}{ Number of cases } \\
\hline & \multicolumn{4}{|c|}{ Adult } & \multicolumn{4}{|c|}{ Child } & \multicolumn{4}{|c|}{ Unknown } & \multirow{2}{*}{ Total } \\
\hline & Male & Female & Unknown & Total & Male & Female & Unknown & Total & Male & Female & Unknown & Total & \\
\hline Foot & 34 & 5 & 0 & 39 & 1 & 0 & 0 & 1 & 1 & 0 & 1 & 2 & 42 \\
\hline Leg & 22 & 0 & 0 & 22 & 1 & 0 & 0 & 1 & 2 & 0 & 1 & 3 & 26 \\
\hline Lymph node(s) & 3 & 1 & 0 & 4 & 11 & 2 & 0 & 13 & 1 & 1 & 0 & 2 & 19 \\
\hline Hand & 16 & 1 & 0 & 17 & 0 & 0 & 0 & 0 & 0 & 0 & 1 & 1 & 18 \\
\hline Arm & 10 & 0 & 1 & 11 & 0 & 0 & 0 & 0 & 1 & 0 & 0 & 1 & 12 \\
\hline Thigh & 6 & 0 & 0 & 6 & 0 & 0 & 0 & 0 & 1 & 0 & 0 & 1 & 7 \\
\hline Knee & 5 & 0 & 0 & 5 & 0 & 0 & 0 & 0 & 0 & 0 & 0 & 0 & 5 \\
\hline Ankle & 4 & 0 & 0 & 4 & 0 & 0 & 0 & 0 & 0 & 0 & 0 & 0 & 4 \\
\hline Trunk & 3 & 1 & 0 & 4 & 0 & 0 & 0 & 0 & 0 & 0 & 0 & 0 & 4 \\
\hline Orbit & 1 & 0 & 0 & 1 & 0 & 0 & 0 & 0 & 0 & 0 & 0 & 0 & 1 \\
\hline Upper lid & 0 & 0 & 0 & 1 & 0 & 0 & 1 & 0 & 0 & 0 & 0 & 0 & 1 \\
\hline Mandible & 0 & 0 & 0 & 0 & 1 & 0 & 0 & 1 & 0 & 0 & 0 & 0 & 1 \\
\hline Axilla & 1 & 0 & 0 & 1 & 0 & 0 & 0 & 0 & 0 & 0 & 0 & 0 & 1 \\
\hline Pharynx & 1 & 0 & 0 & 1 & 0 & 0 & 0 & 0 & 0 & 0 & 0 & 0 & 1 \\
\hline Tonsil & 0 & 1 & 0 & 1 & 0 & 0 & 0 & 0 & 0 & 0 & 0 & 0 & 1 \\
\hline Unknown & 3 & 1 & 0 & 4 & 0 & 0 & 0 & 0 & 0 & 0 & 0 & 0 & 4 \\
\hline Total & 109 & 10 & 1 & 120 & 15 & 2 & 0 & 17 & 6 & 1 & 2 & 9 & $146^{*}$ \\
\hline
\end{tabular}

* including multiple lesions.

Table 5 Anatomical distribution of 135 cases of Burkitt's lymphoma (BL)

\begin{tabular}{lrrrr}
\hline \multirow{2}{*}{ Localization } & \multicolumn{4}{c}{ Number of cases } \\
\cline { 2 - 5 } & Male & Female & Unknown & Total \\
\hline Oral cavity (includ. Nasal cavity) & 17 & 12 & 0 & 29 \\
Maxilla and Mandibula (includ. Cheek, Orbit and Eye) & 19 & 9 & 1 & 29 \\
Abdominal mass & 8 & 7 & 0 & 15 \\
Unknown lymph node & 9 & 6 & 0 & 15 \\
Ovary & 0 & 14 & 0 & 14 \\
Neck (includ. Cervical lymph node and Thyroid) & 8 & 5 & 0 & 13 \\
Inguinal lymph node and Groin & 3 & 1 & 0 & 4 \\
Kidney & 1 & 2 & 0 & 3 \\
Axillary lymph node & 0 & 2 & 0 & 2 \\
Mediastinum & 0 & 1 & 0 & 1 \\
Spleen & 1 & 0 & 0 & 1 \\
Head & 1 & 0 & 0 & 1 \\
Shoulder & 0 & 1 & 0 & 1 \\
Hand & 1 & 0 & 0 & 1 \\
Hip & 1 & 0 & 0 & 1 \\
Mesenteric lymph node & 1 & 0 & 0 & 1 \\
Unknown & 4 & 0 & 0 & 4 \\
\hline Total & 73 & 61 & 1 & 135 \\
\hline
\end{tabular}


Table 6 Geographical and sex distribution of Kaposi's sarcoma (KS) and Burkitt's lymphoma (BL)

\begin{tabular}{|c|c|c|c|c|c|c|c|c|c|}
\hline \multirow{2}{*}{ Province } & \multirow{2}{*}{ District } & \multicolumn{4}{|c|}{ Number of KS } & \multicolumn{4}{|c|}{ Number of BL } \\
\hline & & Male & Female & Unknown & Total & $\overline{\text { Male }}$ & Female & Unknown & Total \\
\hline \multirow{4}{*}{ Western } & Bungoma & 9 & 1 & 0 & 10 & 0 & 0 & 0 & 0 \\
\hline & Busia & 5 & 0 & 0 & 5 & 1 & 0 & 0 & 1 \\
\hline & Kakamega & 14 & 3 & 1 & 18 & 9 & 12 & 0 & 21 \\
\hline & (Total) & 28 & 4 & 1 & 33 & 10 & 12 & 0 & 22 \\
\hline \multirow[t]{5}{*}{ Nyanza } & Siaya & 8 & 2 & 0 & 10 & 3 & 2 & 0 & 5 \\
\hline & Kisumu & 24 & 0 & 0 & 24 & 32 & 31 & 1 & 64 \\
\hline & South Nyanza & 11 & 1 & 0 & 12 & 11 & 4 & 0 & 15 \\
\hline & Kisii & 7 & 1 & 0 & 8 & 1 & 5 & 0 & 6 \\
\hline & (Total) & 50 & 4 & 0 & 54 & 47 & 42 & 1 & 90 \\
\hline \multirow[t]{12}{*}{ Rift Valley } & Turkana & 0 & 0 & 0 & 0 & 0 & 1 & 0 & 1 \\
\hline & West Pokot & 3 & 0 & 0 & 3 & 0 & 1 & 0 & 1 \\
\hline & Trans Nzoia & 2 & 0 & 0 & 2 & 2 & 1 & 0 & 3 \\
\hline & Uasin Gishu & 4 & 0 & 0 & 4 & 0 & 0 & 0 & 0 \\
\hline & Elgeyo Marakwet & 1 & 0 & 0 & 1 & 0 & 0 & 0 & 0 \\
\hline & Baringo & 1 & 0 & 0 & 1 & 1 & 0 . & 0 & 1 \\
\hline & Nandi & 3 & 0 & 0 & 3 & 2 & 0 & 0 & 2 \\
\hline & Nakuru & 13 & 2 & 1 & 16 & 6 & 3 & 0 & 9 \\
\hline & Kericho & 3 & 1 & 0 & 4 & 4 & 1 & 0 & 5 \\
\hline & Narok & 1 & 1 & 0 & 2 & 0 & 0 & 0 & 0 \\
\hline & Others & 0 & 0 & 0 & 0 & 0 & 0 & 0 & 0 \\
\hline & (Total) & 31 & 4 & 1 & 36 & 15 & 7 & 0 & 22 \\
\hline Unknown & & 0 & 1 & 0 & 1 & 1 & 0 & 0 & 1 \\
\hline Total & & 109 & 13 & 2 & 124 & 73 & 61 & 1 & 135 \\
\hline
\end{tabular}

Anatomical distribution of $K S$ and $B L$

The anatomical distribution of $\mathrm{KS}$ and $\mathrm{BL}$ are shown in Tables 4 and 5 respectively. The most common sites of primary lesion of KS in adults were the foot, followed by the leg, hand and arm. In children, the primary lesion of KS was predominantly of lymph node(s) origin. The most common sites of primary lesion of BL were the oral cavity, followed by the maxilla, mandibula, abdominal cavity, lymph nodes and ovary.

Geographical distribution of $K S$ and $B L$

Tables 6 and 7 show the geographical distribution of KS and BL. Out of 124 collected cases of KS, 54 were from Nyanza Province, 36 from Rift Valley Province and 33 from Western Province (Table 6). The estimated incidence of KS per 100,000 population in each province and district for the eight-year period was as follows: Nyanza Province showed the highest incidence of 2.12, followed by 1.80 in Western Province and 1.11 in Rift Valley Province (Table 7). Kisumu District in Nyanza Province showed the highest incidence of 4.98, followed by Nakuru District of Rift Valley Province with 3.06 and Siaya District of Nyanza Province with 2.11 (Table 7). 
Table 7 Geographical distribution of Kaposi's sarcoma (KS) and Burkitt's lymphoma (BL) in western Kenya (per 100,000 population)

\begin{tabular}{|c|c|c|c|c|c|c|}
\hline \multirow{2}{*}{ Province } & \multirow{2}{*}{ District } & \multirow{2}{*}{ Population in ' $000 \mathrm{~s}^{*}$} & \multirow{2}{*}{$\mathrm{KS}$} & $\mathrm{KS}$ & \multirow{2}{*}{$\mathrm{BL}$} & \multirow{2}{*}{$\frac{\mathrm{BL}}{100,000 \text { population }}$} \\
\hline & & & & $\overline{100,000 \text { population }}$ & & \\
\hline \multirow[t]{4}{*}{ Western } & Bungoma & 503.9 & 10 & 1.98 & 0 & 0.00 \\
\hline & Busia & 297.8 & 5 & 1.68 & 1 & 0.34 \\
\hline & Kakamega & $1,030.9$ & 18 & 1.75 & 21 & 2.04 \\
\hline & (Total) & $1,832.7$ & 33 & 1.80 & 22 & 1.20 \\
\hline \multirow[t]{5}{*}{ Nyanza } & Siaya & 474.5 & 10 & 2.11 & 5 & 1.05 \\
\hline & Kisumu & 482.3 & 24 & 4.98 & 64 & 13.27 \\
\hline & South Nyanza & 817.6 & 12 & 1.47 & 15 & 1.83 \\
\hline & Kisii & 869.5 & 8 & 0.92 & 6 & 0.69 \\
\hline & (Total) & $2,544.0$ & 54 & 2.12 & 90 & 3.54 \\
\hline \multirow[t]{12}{*}{ Rift Valley } & Turkana & 142.7 & 0 & 0.00 & 1 & 0.70 \\
\hline & West Pokot & 158.7 & 3 & 1.89 & 1 & 0.63 \\
\hline & Trans Nzoia & 259.5 & 2 & 0.77 & 3 & 1.16 \\
\hline & Uasin Gishu & 300.8 & 4 & 1.33 & 0 & 0.00 \\
\hline & Elgeyo Marakwet & 148.9 & 1 & 0.67 & 0 & 0.00 \\
\hline & Baringo & 203.8 & 1 & 0.49 & 1 & 0.49 \\
\hline & Nandi & 299.3 & 3 & 1.00 & 2 & 0.67 \\
\hline & Nakuru & 522.7 & 16 & 3.06 & 9 & 1.72 \\
\hline & Kericho & 633.3 & 4 & 0.63 & 5 & 0.79 \\
\hline & Narok & 210.3 & 2 & 0.96 & 0 & 0.00 \\
\hline & Others & 211.4 & 0 & 0.00 & 0 & 0.00 \\
\hline & (Total) & $3,240.4$ & 36 & 1.11 & 22 & 0.68 \\
\hline Unknown & & - & 1 & - & 1 & - \\
\hline Total & & $7,617.0$ & 124 & 1.63 & 135 & 1.77 \\
\hline
\end{tabular}

* A demographic structure was obtained from the Kenya Population Census 1979 (Government of Kenya, 1979).

Table 8 Ethnical distribution of Kaposi's sarcoma (KS) and Burkitt's lymphoma (BL) (per 100,000 population)

\begin{tabular}{lccccc}
\hline Ethnic Group & $\begin{array}{c}\text { Population in '000s } \\
(1979, \text { estimated) }\end{array}$ & KS & KS & BL & BL \\
\hline Luo & $1,955.9$ & 50 & 2.000 population & & 100,000 population \\
Luhya & $2,119.7$ & 35 & 1.65 & 22 & 4.35 \\
Kalenjin & $1,652.2$ & 17 & 1.03 & 13 & 1.04 \\
Kisii & 944.1 & 9 & 0.95 & 11 & 0.79 \\
Teso & 132.7 & 1 & 0.75 & 0 & - \\
Kikuyu & $3,202.8^{*}$ & 11 & 0.34 & 0 & - \\
Turkana & 207.2 & 0 & - & 1 & 0.48 \\
Arab & - & 0 & - & 1 & - \\
Unknown & - & 1 & - & 2 & - \\
\hline
\end{tabular}

* Exact number of their population in western Kenya is unclear. 
Table 9 Ethnical incidence of Kaposi's sarcoma (KS) and Burkitt's lymphoma (BL) amongst malignant tumors

\begin{tabular}{|c|c|c|c|c|c|c|}
\hline \multirow{2}{*}{$\begin{array}{l}\text { Ethnic Group } \\
\text { Luo }\end{array}$} & \multicolumn{2}{|c|}{$\begin{array}{c}\text { No. of } \\
\text { malig. tumor }\end{array}$} & \multirow{2}{*}{$\begin{array}{r}\mathrm{KS} \\
46\end{array}$} & \multirow{2}{*}{$\frac{\frac{\mathrm{KS}}{\text { malig. tumor }}(\%)}{7.36}$} & \multirow{2}{*}{$\begin{array}{r}\mathrm{BL} \\
48\end{array}$} & \multirow{2}{*}{$\frac{\frac{\mathrm{BL}}{\text { malig. tumor }}(\%)}{7.68}$} \\
\hline & Male & 625 & & & & \\
\hline & Female & 765 & 4 & 0.52 & 36 & 4.70 \\
\hline \multirow{6}{*}{ Luhya } & Unknown & 6 & 0 & - & 1 & 16.67 \\
\hline & (Total) & 1,396 & 50 & 3.58 & 85 & 6.09 \\
\hline & Male & 347 & 30 & 8.65 & 10 & 2.88 \\
\hline & Female & 391 & 1 & 0.26 & 12 & 3.07 \\
\hline & Unknown & 9 & 4 & 44.44 & 0 & - \\
\hline & (Total) & 747 & 35 & 4.69 & 22 & 2.95 \\
\hline \multirow[t]{4}{*}{ Kalenjin } & Male & 402 & 15 & 3.73 & 8 & 1.99 \\
\hline & Female & 472 & 2 & 0.42 & 5 & 1.06 \\
\hline & Unknown & 22 & 0 & - & 0 & - \\
\hline & (Total) & 896 & 17 & 1.90 & 13 & 1.45 \\
\hline \multirow[t]{4}{*}{ Kisii } & Male & 165 & 8 & 4.85 & 5 & 3.03 \\
\hline & Female & 153 & 1 & 0.65 & 6 & 3.92 \\
\hline & Unknown & 1 & 0 & - & 0 & - \\
\hline & (Total) & 319 & 9 & 2.82 & 11 & 3.45 \\
\hline \multirow[t]{4}{*}{ Teso } & Male & 8 & 1 & 12.50 & 0 & - \\
\hline & Female & 9 & 0 & - & 0 & - \\
\hline & Unknown & 1 & 0 & - & 0 & - \\
\hline & (Total) & 18 & 1 & 5.56 & 0 & - \\
\hline \multirow[t]{4}{*}{ Kikuyu } & Male & 181 & 9 & 4.97 & 0 & - \\
\hline & Female & 303 & 2 & 0.66 & 0 & - \\
\hline & Unknown & 18 & 0 & - & 0 & - \\
\hline & (Total) & 502 & 11 & 2.19 & 0 & - \\
\hline Others & (Total) & 365 & 1 & 0.27 & 4 & 1.10 \\
\hline Total & & 4,243 & 124 & 2.92 & 135 & 3.18 \\
\hline
\end{tabular}

Out of a total of 135 collected BL cases, 90 were from Nyanza Province, and 22 each from both Western Province and Rift Valley Province (Table 6). The estimated incidence of BL per 100,000 population in each province and district for the eight-year period was as follows: Nyanza Province showed the highest incidence of 3.54, followed by 1.20 in Western Province and 0.68 in Rift Valley Province (Table 7). Kisumu District in Nyanza Province showed the highest incidence of 13.27, followed by Kakamega District of Western Province with 2.04, South Nyanza District of Nyanza Province with 1.83, Nakuru District of Rift Valley Province with 1.72, Trans Nzoia District of Rift Valley Province with 1.16 and Siaya District of Nyanza Province with 1.05 (Table 7). High incidence rates of both diseases appeared in Kisumu, Siaya and South Nyanza Districts of Nyanza Province, in the tropical savannah around Lake Victoria, Nakuru District of Rift Valley Province, in the tropical highland, and Kakamega District of Western Province, in the tropical savannah. When the numbers of cases of $\mathrm{KS}$ and $\mathrm{BL}$ were compared by region, there was a significant positive 
correlation $(r=0.819, p<0.001)$, i. e., a high incidence of $\mathrm{KS}(\mathrm{BL})$ cases were found in regions which exhibited a high incidence of BL (KS) cases.

Figures 2, 3 and 4 are adapted from figures in Health and Disease in Kenya (Vogel et al., 1974) showing these factors for references. The occurrence of KS and BL was analysed in relation to the altitude, mean annual temperature and mean annual rainfall in western Kenya. Among the factors the annnual rainfall correlated with the occurence of $\mathrm{KS}$, but it was not significant statistically. As for $\mathrm{BL}$, the temperature gave the highest correlation value, but again without significance.

\section{Ethnical distribution}

Table 8 shows the ethnical distribution of KS and BL per 100,000 population for the eight -year period between 1979 to 1986. In the case of KS, the Luo, the main inhabitants of Nyanza Province, around Lake Victoria showed the highest incidence with 2.56, followed by the Luhya, the main inhabitants of Western Province, with 1.65, the Kalenjin, the inhabitants of the tropical highland in Rift Valley Province, with 1.03, and the Kisii, the inhabitants of highland area of Nyanza Province, with 0.95 . On the other hand, the highest incidence of BL was seen among the Luo with 4.35 , followed by the Kisii with 1.17, the Luhya with 1.04, and the Kalenjin with 0.79. Table 9 shows the ethnical incidence of KS and BL amongst malignant tumors. The Luhya had a higher rate of KS than the Kisii $(\mathrm{p}<0.05)$, Kikuyu $(\mathrm{p}<$ $0.05)$ and Kalenjin $(\mathrm{p}<0.01)$. There was no significant difference between the Luhya and the Luo (by the Chi-square test, using 4,243 cases of malignant tumors). The number of cases of Teso was so small that could not be analysed. The highest incidence of both KS and BL appeared in the Luo, Luhya and Kisii. The analysed results showed a clear association between the ethnic group and the occurrence rate of KS $(p<0.025)$ or $B L(p<0.001)$.

Table 10 Child type Kaposi's sarcoma (KS) in western Kenya

\begin{tabular}{cccllll}
\hline Case & Age & Sex & \multicolumn{1}{c}{ Site of lesion } & Ethnic group & \multicolumn{1}{c}{ District } & Province \\
\hline 1 & 1 & M & Inguinal lymph node & Luhya & Busia & Western \\
2 & $1 y 6 \mathrm{~m}$ & M & Generalized lymph nodes & Luo & South Nyanza & Nyanza \\
3 & $1 \mathrm{y} 8 \mathrm{~m}$ & M & Generalized lymph nodes & Luo & Kisumu & Nyanza \\
4 & $1 \mathrm{y} 9 \mathrm{~m}$ & M & Generalized lymph nodes & Luhya & Kakamega & Western \\
5 & $1 \mathrm{y} 9 \mathrm{~m}$ & M & Generalized lymph nodes & Luo & Siaya & Nyanza \\
6 & $2 \mathrm{y} 6 \mathrm{~m}$ & M & Unknown lymph node & Luhya & Kisumu & Nyanza \\
7 & 5 & F & Generalized lymph nodes & Luo & South Nyanza & Nyanza \\
8 & 6 & M & Unknown lymph node & Luo & Kisumu & Nyanza \\
9 & 7 & M & Generalized lymph nodes & Luo & Kakamega & Western \\
10 & 7 & F & Mandibula & Luo & Siaya & Nyanza \\
11 & 8 & M & Elbow lymph node & Kisii & Kisii & Nyanza \\
12 & 9 & M & Foot & Luo & South Nyanza & Nyanza \\
13 & 10 & F & Unknown lymph node & Luhya & Kakamega & Western \\
14 & 11 & M & Leg & Luo & Kisumu & Nyanza \\
15 & 12 & M & Upper lid & Luo & Busia & Western \\
16 & 12 & M & Cervical lymph node & Luo & Kisumu & Nyanza \\
17 & Child* & M & Generalized lymph nodes & Luo & Kisumu & Nyanza \\
\hline
\end{tabular}

* Exact age in unknown. 


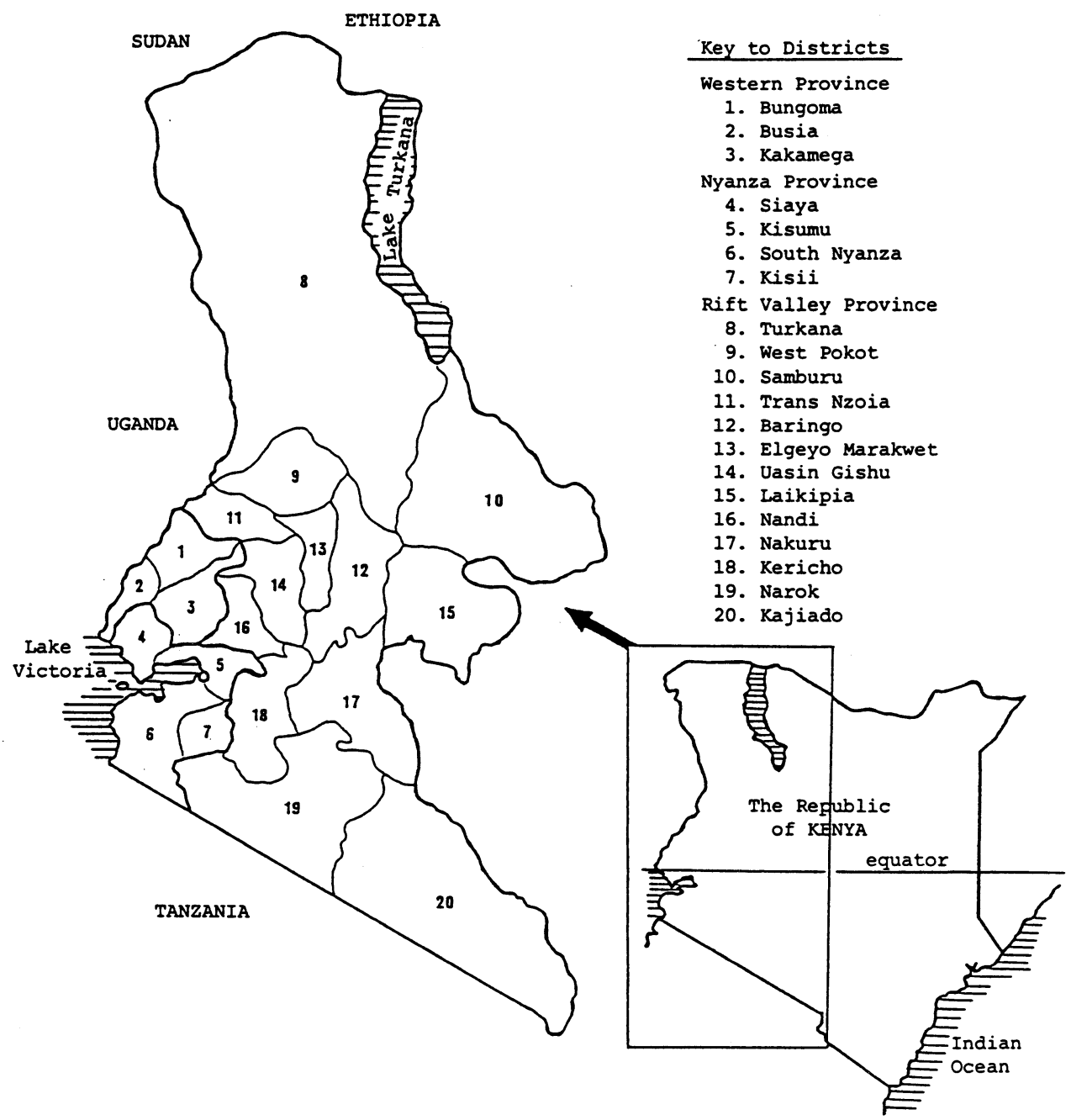

Figure 1 Map of western Kenya showing districts. (Adapted from figures in Vogel et al.: Health and Disease in Kenya. East African Literature Bureau, 1974) 


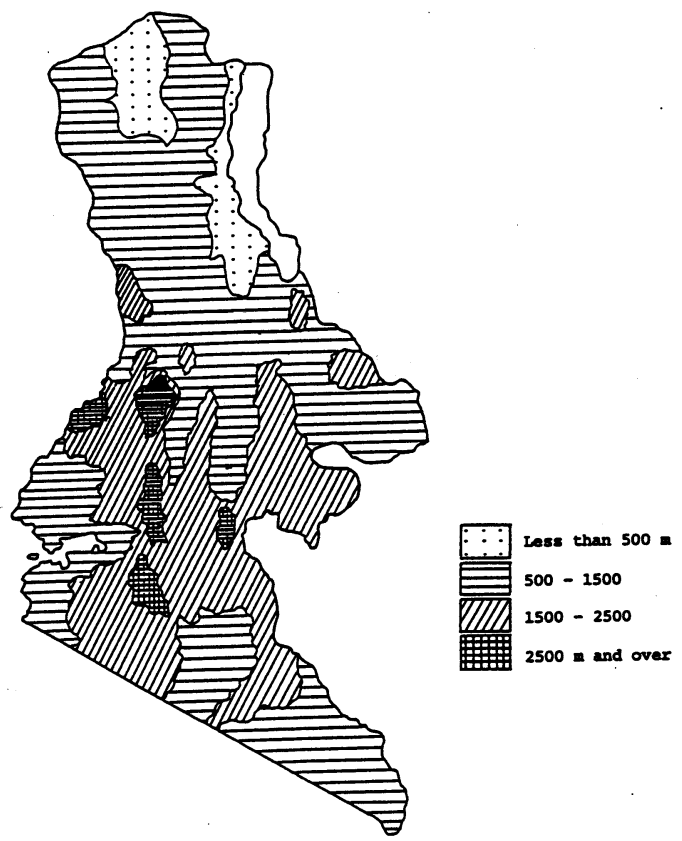

Figure 2 Map of western Kenya showing altitudes above sea level. (Adapted from figures in Vogel et al:: Health and Disease in Kenya. East African Literature Bureau, 1974)

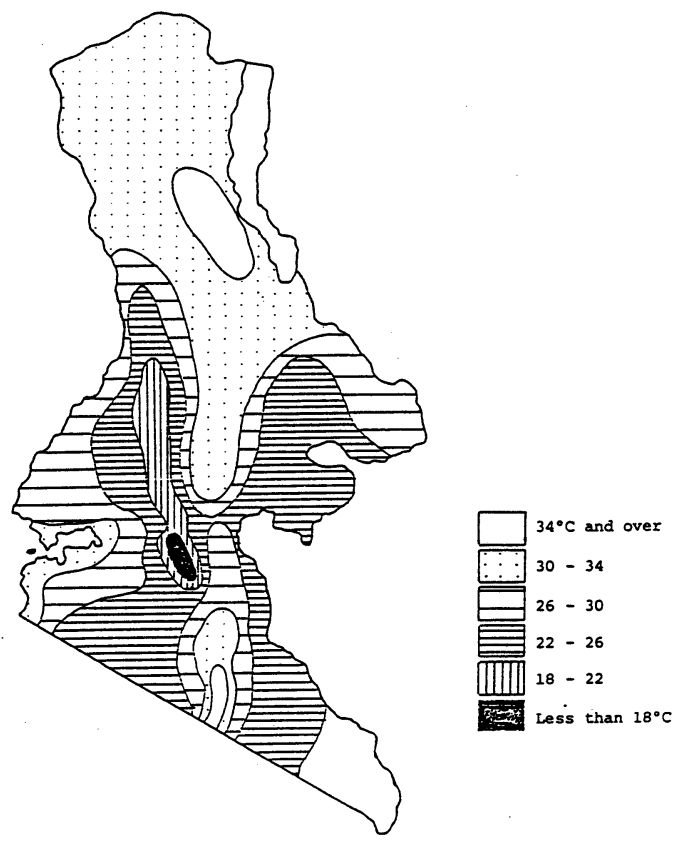

Figure 3 Map of western Kenya showing mean annual temperature. (Adapted from figures in Vogel et al:: Health and Disease in Kenya. East African Literature Bureau, 1974) 


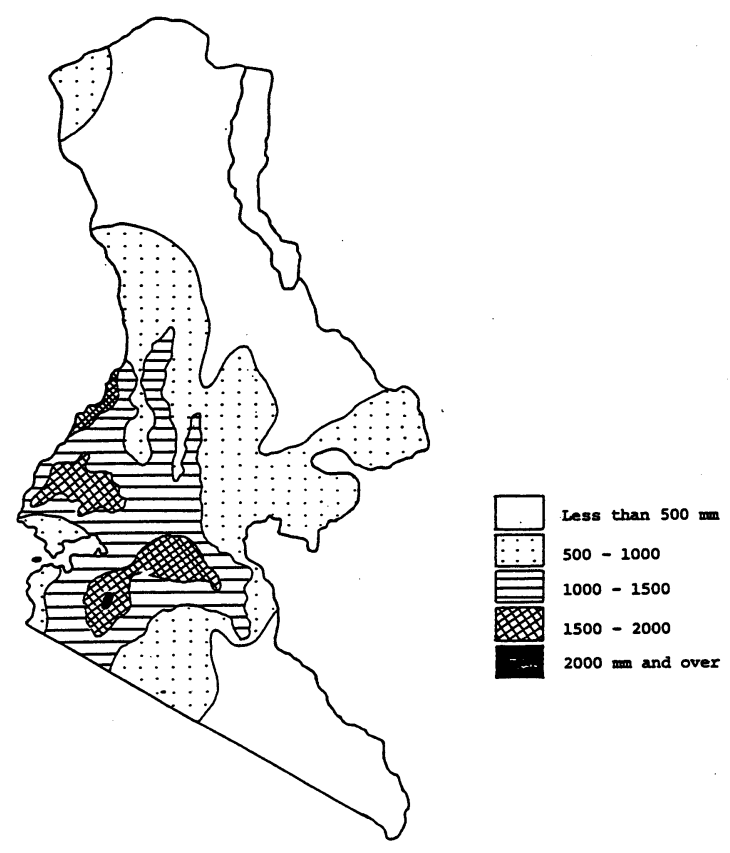

Figure 4 Map of western Kenya showing mean annual rain fall. (Adapted from figures in Vogel et al.: Health and Disease in Kenya. East African Literature Bureau, 1974)

\section{$K S$ in children and $B L$}

Table 10 shows the 17 cases of KS found in children (under 14 years old) between 1979 and 1986. Twelve cases in all appeared in Nyanza Province, followed by 5 cases in Western Province, while no case was reported from Rift Valley Province. Kisumu District had the largest number with 6 cases, followed by South Nyanza District and Kakamega District with 3 cases each, Busia District and Siaya District with 2 cases each, and Kisii District with one case. Significantly more cases were found in Kisumu District than Busia District $(p<0.05)$ or Kisii District $(p<0.01)$. As for ethnic group, 12 cases of KS in children were from the the Luo, with 4 cases of the Luhya and one case of the Kisii. KS in children were more prevalent in the Luo than in the Luhya $(\mathrm{p}<0.05)$ or the Kisii $(\mathrm{p}<0.05)$. There was a significant level of association of $\mathrm{KS}$ in children with region $(\mathrm{p}<0.05)$ and ethnic group $(\mathrm{p}<0.05)$. Majority of BL cases were found in children under 14 years old (Table 3). Ethnically, the Luo had a higher rate of BL than the Kisii, Luhya, and Kalenjin $(\mathrm{p}<0.01)$ (Table 8). Geographically, Kisumu District had a higher rate of BL than Kakamega, South Nyanza, Siaya and Kisii Districts $(\mathrm{p}<0.01) \quad$ (Table 7) (by the Chi-square test, using the number of KS in children and $\mathrm{BL}$ against the total populations in each ethnic group and region). The occurrence rate of $\mathrm{BL}$ in ethnic groups and regions showed a clear association of BL with ethnic group and with region. The geographical and ethnical distributions of $\mathrm{KS}$ and $\mathrm{BL}$ coincided far more in children than in the adult population. 


\section{Discussion}

The Republic of Kenya stands almost exactly astride the equator; its area is $569,137 \mathrm{~km}^{2}$ and its population is 15,327,000 (Bhushan, 1982). Western Kenya (Western, Nyanza and Rift Valley Provinces) accounts for one third of the whole country, $189,578 \mathrm{~km}^{2}$, in area and about one half, 7,617,000, in population (Bhushan, 1982). It is bounded by Sudan and Ethiopia on the north, Uganda on the west and Tanzania on the south, and consists of three provinces, namely, Western, Nyanza and Rift Valley Provinces. These provinces are divided into three, four and thirteen districts respectively (Figure 1 ). These areas experience a wide variation of climatic conditions (Figure 2, 3 and 4). The most northern part, Turkana District, and the most southern part, Kajiado District, are dry desert or dry tropical savannah and have mean annual rainfalls of 100 to $200 \mathrm{~mm}$ and 300 to $700 \mathrm{~mm}$ respectively, and mean annual temperatures of 33 to $36^{\circ} \mathrm{C}$ and 22 to $33^{\circ} \mathrm{C}$ respectively. The altitudes of these areas are $650 \mathrm{~m}$ and 650 to $1,000 \mathrm{~m}$ respectively. On the contrary, the central part of Rift Valley Province is tropical highland with an altitude of 1,500 to $2,000 \mathrm{~m}$, a mean annual rainfall of 1,200 to $2,000 \mathrm{~mm}$ and a mean annual temperature of 18 to $22^{\circ} \mathrm{C}$. Western Province is tropical savannah with an altitude of 1,200 to $2,000 \mathrm{~m}$, a mean annual rainfall of 1,250 to $1,750 \mathrm{~mm}$ and a mean annual temperature of 26 to $30^{\circ} \mathrm{C}$. Nyanza Province is tropical savannah situated around Lake Victoria with altitude of 1,100 to $1,800 \mathrm{~m}$, a mean annual rainfall of 1,000 to $1,750 \mathrm{~mm}$ and a mean annual temperature of 26 to $34^{\circ} \mathrm{C}$.

When the geographical distribution of endemic KS and African BL per 100,000 population and the incidence of both diseases amongst malignant tumors in western Kenya were considered, coincidences of both diseases were observed in Kisumu District around Lake Victoria in Nyanza Province, Kakamega District in Western Province, Siaya District in Nyanza Province and Nakuru District in Rift Valley Province. Kisumu and Siaya Districts around Lake Victoria and Kakamega District consist of relatively moist tropical savannah whereas Nakuru District is situated in tropical highland which has relatively moist climatic conditions. Although the author could not detect any apparent statistical significances, it is likely that some environmental factors, such as high temperature (mean annual temperature over $26^{\circ} \mathrm{C}$ ) and humidity (annual rainfall over $1,000 \mathrm{~mm}$ ), influence the causation of $\mathrm{KS}$ and $\mathrm{BL}$ in western Kenya. And ethnically, a high incidence of $\mathrm{KS}$ and $\mathrm{BL}$ appeared among the Luhya, descended from the Bantu, and the Luo, descended from the Nilotic groups. These ethnic groups are from different origins (Fedders and Salvadori, 1979), but are living in moist and high temperature areas. These findings suggest that some environmental factors and some transmissible agents influence more the causation of endemic KS and African BL rather than genetic factors.

Although EBV is now known as the causative agent of BL (Epstein et al., 1964; Old et al., 1966; Henle et al., 1969, 1973; de Schryver et al., 1969; Gunven et al., 1970; KaschkaDierich et al., 1976), most studies of American cases have failed to demonstrate an association between high titers of anti-EBV and BL, and it was suggested that, even if EBV is etiologic for BL, it is only one of several factors (Linder and Purtio, 1984). Also it has been suggested that EBV may initiate a lymphoid tumor if it infects a susceptible individual whose immunological response has been altered by malaria, especially P. falciparum (Hutt, 1970). As a result of similar etiological conditions, CMV has been linked with endemic KS in Africa (Burkes et al., 1985). 
With special reference to KS in children, it has been suggested that preceding persistent infection with malaria, especially $P$. falciparum before CMV infection may play a role as one of the etiological factors of KS (Safai et al., 1980). It was recognized that continuous stimulation with foreign antigens might cause a relative immunodeficiency in Africa (Oettle, 1962; Master et al., 1970; Taylor et al., 1971b). Although the tropical savannah around Lake Victoria in western Kenya is a holoendemic area of P. falciparum (Vogel et al., 1974), it is not known whether malaria infections could be an etiological cofactor of endemic KS and African BL or not. However, some environmental cofactors, including climatic conditions, life styles of the inhabitants and other unknown causative agents, might play a role in the causation of endemic KS and African BL. Furthermore, unknown transmissible agents might be one of the etiological cofactors of the both diseases, in a similar way to the relationship between epidemic KS and malignant B-cell lymphoma in AIDS.

According to this statistical study on the geographical distribution of endemic KS and African $\mathrm{BL}$, a relalatively high temperature and moist climatic conditions were considered to be related to the high incidence of endemic KS and African BL in western Kenya. No case of $\mathrm{KS}$ and only a few cases of BL were found among the inhabitants of desert or semi-desert areas. No other tumors showed above mentioned tendencies. The geographical and ethnical coincidence of $\mathrm{KS}$ and $\mathrm{BL}$ was more clear in the child population than in the adult. These results suggest that there is a geographical coincidence of $\mathrm{KS}$ and $\mathrm{BL}$ based on same etiological cofactors including high temperature, high humidity, unknown transmissible agents, and probably genetic factors and life styles. This was mainly demonstrated in Nyanza Province around Lake Victoria in western Kenya.

\section{ACKNOWLEDGEMENTS}

The author is grateful to Prof. Hideyo Itakura and all the members in Department of Pathology, Institute of Tropical Medicine, Nagasaki University for their critical discussion and kind help during the course of this study. The author is greatly indebeted to relevant officers of Government of Kenya, especially Dr. Noah O. Kamidigo, for their kind permission to study the Kenyan materials. The author's thanks are extended to Dr. Nobu Ohwatari, Department of Environmental Physiology, and Dr. Eisaku Kimura, Department of Parasitology, Institute of Tropical Medicine, Nagasaki University for their kind advices for the statistical analysis of the research data.

\section{REFERENCES}

1 ) Bhushan, K. (1982): Kenya; 1982-1983, Uhuru 18 year book, Newspread International, Nairobi

2 ) Bluefarb, S. M. (1957): Kaposi's sarcoma, multiple idiopathic hemorrhagic sarcoma., pp 171. Charles. C. Thomas, Springfield, Illinois, U. S. A.

3 ) Boldogh, I., Beth, E., Huang, E. S., Kyalwazi, S. K. and Giraldo, G. (1981): Kaposi's sarcoma. IV. Detection of CMV DNA, CMV RNA and CMNA in tumor biopsies, Int. J. Cancer, 28, 469 $-474$

4 ) Burkes, R. L., Gal, A. A., Stewart, M. L. Gill, P. S., Abo, W. and Levine, A. M. (1985): Simultaneous occurence of Pneumocystis carinii pneumonia, cytomegalovirus infection, Kaposi's sarcoma, and B-immunoblastic sarcoma in a homosexual man, JAMA., 253 (23), 3425 
$-3428$

5 ) Burkitt, D. B. (1962): Determining the climatic limitations of children's cancer common in Africa, Brit. Med. J., II, 1019-1023

6 ) Burkitt, D. B. and Wright. D. (1966): Geographical and tribal distribution of the African lymphoma in Uganda, Brit. Med. J., I, 569-573

7 ) Burkitt, D. P. (1969): Etiology of Burkitt's lymphoma-an alternative hypothesis to a vectored virus, J. Nat. Cancer Inst., 42, 19-28

8 ) Burkitt, D. P. (1970): Geographical distribution, in Burkitt's lymphoma, ed. by Burkitt, D. P. and Wright, D. H., 66 186-197, E \& S livingstone, Edinburgh \& London

9 ) Centers for Disease Control (1981a): Pneumocystis pneumonia-Los Angeles. M. M. W. R., 30, 250-252

10) Centers for Disease Control (1981b): Follow-up on Kaposi's sarcoma and Pneumocystis pneumonia, M. M. W. R., 30, 409-410

11) Cook. J (1962): The clinical features of Kaposi's sarcoma in the East African Bantu, Acta. Un. Int. Cancer, 18, 388-393

12) Cox, F. H. and Helwig, E. B. (1959): Kaposi's sarcoma, Cancer, 12, 289-298

13) Davies, J. N. P. and Lothe, F. (1962): Kaposi's sarcoma in African children, Acta. Un. Int. Cancer, 18, 372-375

14) de Schryver. A., Fribert., S., Jr., Klein, G., Henle, W., Henle, G., de The, G., Clifford, P., and Ho, H. C. (1969): Epstein-Barr virus (EBV) associated antibody patterns in Carcinoma of the post -nasal space, Clin. Exptl. Immunol., 5, 443-459

15) Epstein, M. A., Achong, B. G. and Barr, Y. M. (1964): Virus particles in cultured lymphoblasts from Burkitt's lymphoma, Lancet I, 702-703

16) Fedders, A. and Salvadori, C. (1979): Peoples and cultures of Kenya, Transafrica, Nairobi and Rex Collins, London

17) Friedman-Kien, A. E. (1981): Disseminated Kaposi-like sarcoma syndrome in young homosexual men, J. Am. Acad. Dermatol., 5, 468-470

18) Giraldo, G., Beth, E., Coeur, P., Vogel, C. L. and Dhru, D. S. (1972a): Kapsoi's sarcoma: a new model in the search for viruses associated with human malignancies, J. nat. Cancer Inst., 49, 1495-1507

19) Giraldo, G. Beth, E. and Haguenau, F. (1972b): Herpes-type virus particles in tissue culture of Kaposi's sarcoma from different geographic regions, J. nat. Cancer Inst., 49, 1509-1526

20) Giraldo, G., Beth, E., Kourilsky, F. M., Henle, M., Henle, W., Mike, V., Huraux, J., Anderson, H., Gharbi, M., Kyalwazi, S. K. and Puissant, A. (1975): Antibody patterns to herpesviruses in Kaposi's sarcoma: serological association of European Kaposi's sarcoma with cytomegalovirus, Int. J. Cancer, 15, 839-848

21) Government of Kenya (1979): Kenya Population Census 1979

22) Gunven, P., Klein, G., Henle, G., Henle, W. and Clifford, P. (1970): Epstein-Barr virus in Burkitt's lymphoma and nasopharyngeal carcinoma, Nature, 228, 1053-1056

23) Henle, G., Henle, W., Clifford, P., Dihel, V., Kafuko, G. W., Kirya, B. G., Klein, G., Morrow, R. H., Munube, G. M. R., Pike, M. C. Tukei, P. M. and Ziegler, J. L. (1969): Antibodies to EB virus in Burkitt's lymphoma and control groups, J. nat. Cancer Inst., 43, 1147-1157

24) Henle, W. and Henle, G. (1973): Evidence for an oncogenic potential of the Epstein-Barr virus, Cancer Research 33, 1419-1423

25) Hutt, M. S. R. (1970): Introduction and historical background in Burkitt's lymphoma. in Burkitt's lymphoma, ed. by Burkitt, D. P. and Wright, D. H., 66 1-5, E \& S Livingstone, Edinburgh \& London

26) Jojot and Laigret, J. (1922): Un cas de tumeurs superficielles multiples observe au Cameroum, Bull. Soc. Path. exot., 15, 956-958 
27) Kaposi, M. (1872): Idiopathisches multiples pigment Sarkom der Haut, Arch. Derm. Syph., 4, $265-273$

28) Kaschka-Dierich, C., Adams, A., Lindahl, T., Bornkamm, G. W., Bjursell, G., Klein, G., Giovanella., B. C. and Singh, S. (1976): Intracellular forms of Epstein-Barr virus DNA in human tumour cells in vivo, Nature, 260, 302-306

29) Keen, P. (1962): The clinical features of Kaposi's sarcoma in the South African Bantu, Acta. Un. Int. Cancer, 18, 380-387

30) Levine, A. M., Meyer, P. R., Begandy, M. K., Parker, J. W., Taylor, C. R., Irwin, L. and Lukes, R. J. (1984): Development of B-cell lymphoma in homosexual men; clinical and immunological findings, Ann. Intern. Med. 100, 7-13

31) Levine, A. M., Gill, P. S., Meyer, P. R., Burkes, R. L., Ross, R., Dworsky, R. D., Krailo, M., Parker, J. W., Lukes, R. J. and Rasheed, S. (1985): Retrovirus and malignant lymphoma in homosexual men, JAMA., 254, 1921-1925

32) Linder, J and Purtilo, D. T. (1984): Burkitt's lymphoma. in Immune Deficiency and Cancer, ed. by Purtilo, I. T., pp 69-99, Plenum Medical Book Company, New York \& London

33) Master, S. P., Taylor, J. F., Kyalwazi, S. K. and Ziegler, J. L. (1970): Immunological studies in Kaposi's sarcoma in Uganda, Brt. Med. J., 1, 600-602

34) Maclean, C. M. U. (1963): Kaposi's sarcoma in Nigeria, Brt. J. Cancer, 17, 195-205

35) Oettle, A. G. (1962): Geographical and racial differences in the frequency of Kaposi's sarcoma as evidence of environmental or genetic causes, Acta. Un. Int. Cancer, 18, 330-363

36) Old, L. J., Boyse, E. A., Oettgen, H. F., de Harven, E., Geering, G., Williamson, B and Clifford, P. (1966): Precipitating antibody in human serum to an antigen present in cultured Burkitt's lymphoma cells, Proc. N. A. S., 56, 1699-1704

37) Rothman, S. (1962): Some clinical aspects of Kaposi's sarcoma in the European and North American populations, Acta. Un. In. Contra. Cancrum., 18, 364-371

38) Safai, B., Mike, V., Giraldo, G., Beth, E. and Good, R. A. (1980): Association of Kaposi's sarcoma with second primary malignancies, Cancer, 45, 1472-1479

39) Schmid, H. (1973): Kaposi's sarcoma in Tanzania: a statistical study of 220 cases, Trop. Geogr. Med., 25, 266-276

40) Slavin, G., Cameron, H. M. and Singh, H. (1969): Kaposi's sarcoma in mainland Tanzania: a report of 117 cases, Br. J. Cancer, 23, 349-357

41) Taylor, J. F., Templeton, A. C., Vogel, C. L. Ziegler, J. L. and Kyalwazi, S. K. (1971a)): Kaposi's sarcoma in Uganda: a clinico-pathological study, Int. J. Cancer, 8, 122-135

42) Taylor, J. F., Templeton, A. C., Kyalwazi, S. and Lubega, A. (1971b): Kaposi's sarcoma in pregnancy: two case reports, Br. J. Surg., 58, 577-579

43) Toriyama, K., Uzuta, F., Itakura, H. and Kamidigo, N. O. (1987a): Geopathological study on endemic Kaposi's sarcoma in Western Kenya, Trop. Med., 29(2), 87-100

44) Toriyama, K., Uzuta, F., Itakura, H. and Kamidigo, N. O. (1987b): Kaposi's sarcoma of lymph node(s) in Western Kenya, Trop. Med., 29(2), 101-106

45) Vogel, L. C., Muller, A. S., Odingo, R. S., Onyango, Z. and Geus, A. (1974): Health and disease in Kenya, East African Literature Bureau, Nairobi

46) Ziegler, J. L., Drew, W. L., Miner, R. C., Mintz, L., Rosenbaum, E., Gershow, J., Lennette, E. T., Greenspan, J., Shillitoe, E., Beckstead, J., Casavant, C. and Yamamoto, K. (1982): Outbreak of Burkitt-like lymphoma in homosexual men, Lancet i, 631-633

47) Ziegler, J. L., Beckstead, J. A., Volberding, P. A., Abrams, D., Levine, A. M., Lukes, R. J., Gill, P. S., Burkes, R. L., Meyer, P. R., Metroka, C. E., Mouradian, J., Moore, A., Riggs, S. A., Butler, J. J., Cabanillas, F. C., Hersh, E., Newell, G. R., Laubenstein, L. J., Knowles, D., Odajnyk, C., Raphael, B., Koziner, B., Urmacher, C. and Clarkson, B. D. (1984): Non-Hodgkin's lymphoma in 90 homosexual men; relationship to generalized lymphadenopathy and acquired im- 
munodeficiency syndrome (AIDS), N. Engl. J. Med., 311, 565-570

48) zur Hausen, H. and Schulte-Holthausen, H. (1970): Presence of EB virus nucleic acid homology in a virus-free line of Burkitt's tumor cells, Nature (London), 227, 245-248 
西ケニアにおける地方病型カポシ肉腫とアフリカ型バーキット

リンパ腫の部族および地理的分布の一致性

鳥山寛

アフリカ型（地方病型）カポシ肉腫（K S ) はアフリカ中央部に多発地帯があり，その地域から 東西南北に地理的に遠ざかるにつれてその頻度は減少すると言われており, 今までに我々が西ケ ニアで行った調查結果もそれを裏付けている。これとは別に赤道をはさんで東アフリカから西ア フリカへ帯状のリンパ腫の多発地帯 (Lymphoma Belt) が存在する。1979年から1986年の 8 年間 にわたって,ケニア西部においてカポシ肉腫と B 細胞型悪性リンパ腫の一つであるアフリカ型 バーキットリンパ腫 $(\mathrm{B} \mathrm{L})$ の, 病理組織学的診断を基礎とした疫学的調查を行い, それらの地理 的および部族的分布を検討した。その結果，KSと B Lの相関性および自然環境や人的環境との 関連性はつぎのようであった。1）K S，B Lともに高温で比較的湿潤な地域に多く見られた。 2 ）部族的には K S ，B Lともに主として熱帯サバンナに居住するルオー族およびルヒア族に多 く見られた。3）乾燥した地域での発生頻度は非常に低かった。4）他の腫瘍では，このような 地理的，部族的，および自然環境的な特徵は著明ではなかった。 5 ) 特に B L と小児型 K S では 地理的, 部族的一致性が強く認められた。これらの結果より, 両疾患の発生には遺伝的あるいは 先天的要因というよりも, 何らかの共通した環境因子の存在や生活様式のより強い関与があるも のと思われる。 